\title{
Sustainability of Traditional Buildings Located in Rural Area
}

\author{
Pınar Usta ${ }^{1}$, Ayşe Arıci ${ }^{2}$, Ahmet Evci ${ }^{3}$, Engin Kepenek ${ }^{4}$ \\ ${ }^{1}$ Departement of Civil Engineering, Suleyman Demirel University \\ ${ }^{2}$ Architecture Lecture, PhD program, Internacionalni University Travnik \\ ${ }^{3}$ Departement of Civil Engineering, Afyon Kocatepe University \\ ${ }^{4}$ Departement of Urban and Regional Planning, Suleyman Demirel University
}

\begin{tabular}{l}
\hline \hline Article Info \\
\hline Article history: \\
Received June $04^{\text {th }}, 2017$ \\
Revised June $15^{\text {th }}, 2017$ \\
Accepted June $17^{\text {th }}, 2017$
\end{tabular}

\section{Keyword:}

Traditional buildings

Rural area

Sustainability

\begin{abstract}
In this days, sensitivity to environmental issues of people increased together with the awareness of the concept of sustainability. The structures, which are built in a rural residential area, are integrated with the natural environment. In Turkey, local traditional structures are structures that can be produced easily in place and materials are being used wisely. These houses which are used renewable natural materials carries a lot of features of the sustainable approach. Traditional structures have been shaped by the region where they are, because of the necessity. In this study, materials and construction systems of the traditional buildings which are located in rural areas are discussed and the buildings have been evaluated the context of ecology and sustainability.
\end{abstract}

\section{Corresponding Author:}

Pinar Usta,

Departement of Civil Engineering,

Suleyman Demirel University,

Suleyman Demirel University Road, Technology Faculty, Çünür 32200, Isparta, Turkey.

Email: pinarusta@sdu.edu.tr

\section{Introduction}

The rural settlements which have natural, historical, and traditional values have an important part of our cultural heritage. Nowadays, this settlements' traditional culture has begun to disappear for several reasons. This traditional texture has included some clever solutions about the usage of material and also sustainable design value. Constituting the majority of part of the historical texture in rural areas has many examples of civil architecture as mostly residential buildings [1].

Traditional buildings have better relations with the environment than the contemporary ones. Traditional buildings in Turkey inherit the values of various civilizations that have lived on these territories for centuries. Environmental factors have played an important role in design of these buildings, which rendered them more harmonized with the environment [2].

Turkish houses have features which unite them with antiseismic construction elsewhere. In almost every part of Turkey, there exist a large proportion of traditional buildings with ecological properties, energy and natural resources save-low environmental impact, which were built at various times in history [2].

Sustainability is a new concept with various perspectives in communities. Cities and rural areas are in the core of attention for developing.

There some elements which are needed to establish a sustainable economy in rural areas that are infrastructure, clean seeds, guidance in crops and livestock production, and credit as well as cooperatives, education, marketing facilities, farm machinery, water supplies, and diverse economic activities. All of them are necessary to establish a sustainable and efficient rural development in each village [3].

Sustainability, as a new paradigm in the past three decades, showed through some scientific evidence that flora and fauna species, water, air, forests, deserts and other ecosystems began to destroy and natural 
resources were overused. Since sustainability is a multidimensional issue (local, regional, and international dimensions), it have to be developed at a level that people live, work and interact with each other and with nature such as local level [3].

The various sustainability issues are interwoven, and the interaction of a building with its surroundings is also important. The environmental issues share, in common, concerns which involve the reduction of the use of non-renewable materials and water, and the reduction of emissions, wastes, and pollutants [4].

Although social, economic, and cultural indicators are of significant importance to the concept of sustainable building, this concept is often based on environmental properties [4]. The concept of sustainability with respect to buildings is still poorly defined. Much of the focus is on the use of energy in buildings. Although sustainable building is a multidimensional concept, attention to the issue often focuses solely on environmental indicators, ignoring the substantial importance of social, economic and cultural indicators. Building sustainability involves various relations between built, natural and social systems [5].

Research in the area of sustainability has produced a significant amount of knowledge that is presented in the literature.

The aim of sustainability assessments is to gather and report information for decision-making during different phases of the construction, design, and use of a building.

\section{Rural Area and Rural Structural Types in Turkey}

Rural population (\% of total population) in Turkey was last measured at 26.60 in 2015 , according to the World Bank. Rural population refers to people living in rural areas as defined by national statistical offices. It is calculated as the difference between total population and urban population. This page has the latest values, historical data, forecasts, charts, statistics, an economic calendar and news for Rural population (\% of total population) in Turkey [6]. Rural population is given Figure 1.

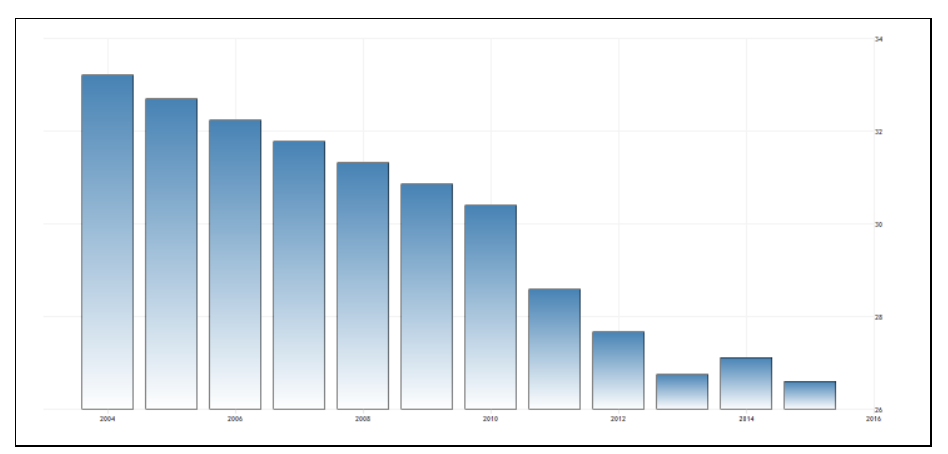

Figure 1. Rural Population of Turkey [6]

Buildings built in rural areas show significant differences depending on climatic conditions, preferred or locally available construction materials, traditions, income levels of the owners and their social habits. Rural housing types show themselves in different forms in different regions of our country. However, a particular type is most common in the area and it is said that this type of rural residence dominates the region [7]. In rural houses, whatever building materials stone, mud brick or wood, primitive construction technology is produced with materials and construction techniques close to each other all over the world [8].

Rural and urban settlements are the units that have different attributions and they do not have similar localities. These settlements have different lifestyles that have distinctive characteristics according to the economical and social activities and the relationship with the nature. Rural areas are qualified according to density of rural functions. These functions are showed up in using of land, in style of production style, in professional structure, in the characteristics of rural area and in the magnetic field of the producer and the service society. Because hegemony of the rural functions means less urban functions at the same time, 'rural areas' can be characterized as places that do not belong to urban areas [9].

The meaning of Rural Residence is the structures built by the dwellers themselves without any engineering services and with the use of local/regional material and technology. In addition to the rural areas many structures, which is located in around the metropolis, have been built without engineering services such as architectural design and static calculation. while building these structures people maintain to use constructional techniques, which are formed by instinctively rather than technically. The fact that the rural residences are still being constructed with the use of similar materials and construction technology all over the 
world is a factor easing their classification. There are many types of structural systems traditional rural domestic architecture in Turkey, resulting from cultural attributes, related to material availability and climate. Modern buildings in the cities are generally built as reinforced concrete. Traditional wooden buildings were generally constructed in the ancient parts of city [10-11].

The rural residences are still being constructed with the use of similar materials and construction technology all over the world is a factor easing their classification [11].

There are different approaches to the classification of rural structures in Turkey. A classification based on the carrier characteristics of the building systems is given in Figure 2.2. and Distribution according to regions is given in Table 2.1. [12].

Table 1. Classification of standard buildings in Turkey [12] (Korkmaz, 2007)

\begin{tabular}{|c|c|c|c|}
\hline Category & Type & Region & Description \\
\hline \multirow[t]{2}{*}{$\begin{array}{l}\text { wooden frame } \\
\text { buildings }\end{array}$} & $\begin{array}{l}\text { Rural } \\
\text { "Himis" }\end{array}$ & $\begin{array}{c}\text { North and West } \\
\text { Anatolia }\end{array}$ & $\begin{array}{l}\text { Frames made of unsorted and } \\
\text { uncomplicated wood logs are } \\
\text { filled with stone or mud } \\
\text { brick. The dams are heavy, } \\
\text { sometimes soil. }\end{array}$ \\
\hline & $\begin{array}{l}\text { Urban } \\
\text { "Bagdadi" }\end{array}$ & West Anatolia & $\begin{array}{l}\text { The thin horizontal slats are } \\
\text { crushed and the wall padding } \\
\text { is light and plastered to the } \\
\text { wooden carrier frames that } \\
\text { are carved and painted } \\
\text { carefully. }\end{array}$ \\
\hline \multirow[t]{5}{*}{$\begin{array}{l}\text { Masonry } \\
\text { Structure }\end{array}$} & Adobe & Central Anatolian & $\begin{array}{l}\text { Walls made of mud, } \\
\text { sometimes plastered with } \\
\text { mud and heavy soil drips. } \\
\text { Lintel and joinery are used } \\
\text { from the tree logs. }\end{array}$ \\
\hline & Stone & Eastern Anatolia & $\begin{array}{l}\text { There are various types from } \\
\text { mud mortar rubble to cement } \\
\text { mortar stones. Sometimes } \\
\text { only basements are made of } \\
\text { stone. }\end{array}$ \\
\hline & Blend Brick & All Region & $\begin{array}{l}\text { It's a common building } \\
\text { material. Lightweight, } \\
\text { economic and also aesthetic } \\
\text { constructions can be } \\
\text { achieved. }\end{array}$ \\
\hline & coring brick & All Region & $\begin{array}{l}\text { It is used for making } \\
\text { buildings such as bricks. The } \\
\text { building is secured with lintel } \\
\text { and lentiles. }\end{array}$ \\
\hline & mixed & All Region & $\begin{array}{l}\text { Concrete reinforced concrete } \\
\text { structures on perforated brick } \\
\text { walls and simple reinforced } \\
\text { concrete columns with adobe } \\
\text { filled walls }\end{array}$ \\
\hline $\begin{array}{l}\text { Reinforced } \\
\text { concrete } \\
\text { Structure }\end{array}$ & & All Region & \begin{tabular}{lrr} 
On-site & pouring & carcass \\
buildings & and & fitted \\
upholstery. & \multicolumn{2}{c}{ Rarely } \\
prefabricated & buildings are \\
also found. & &
\end{tabular} \\
\hline
\end{tabular}




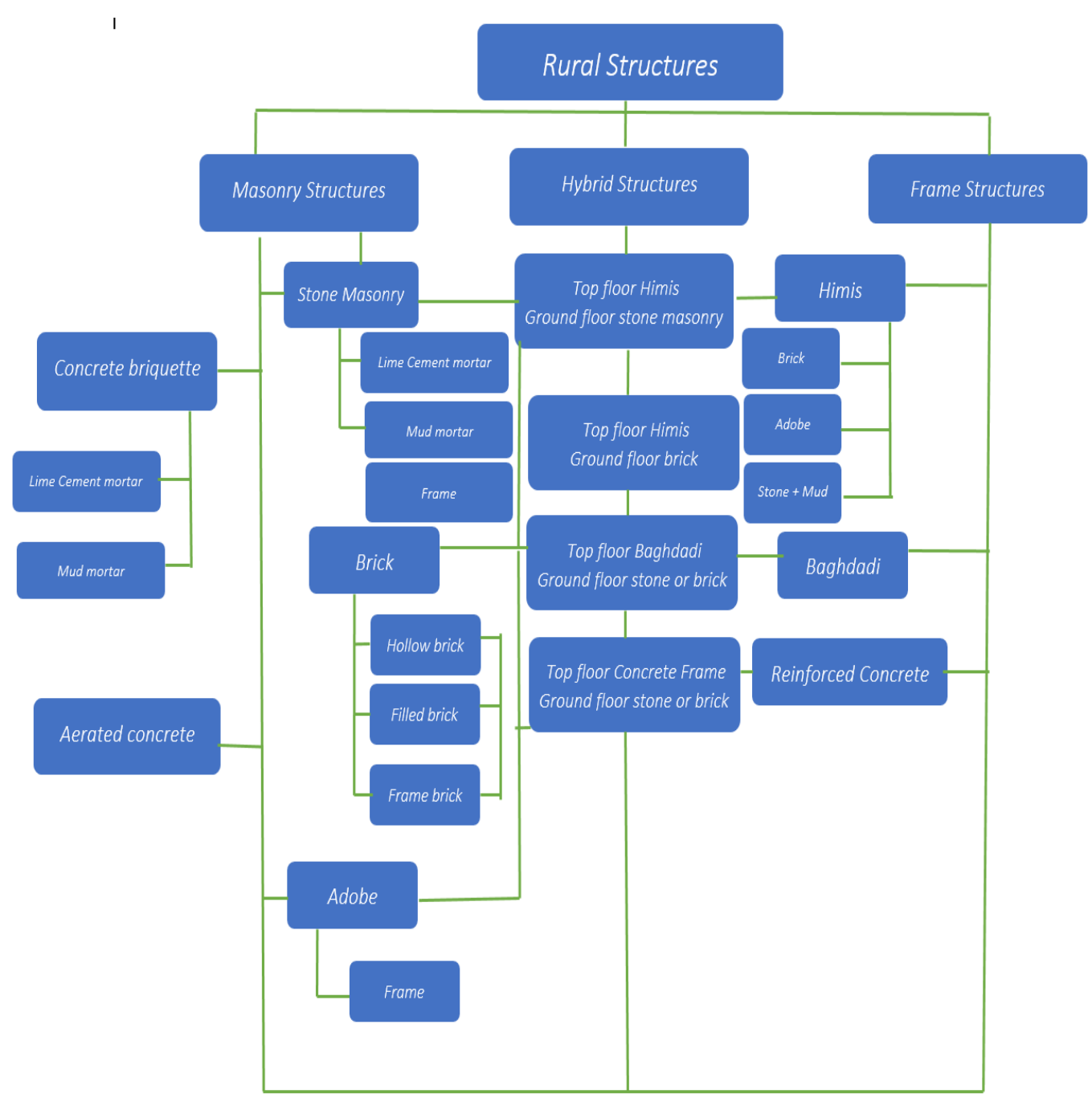

Figure 2. Classification of rural buildings in Turkey

\section{Evaluation of Traditional Housing Architecture in the Context of Sustainability}

In our country, where $35 \%$ of the population lives in rural areas, sustainable rural development is increasingly a challenge. In sustainable rural development with economic, social and environmental dimensions, one of the most important problems is the sustainability of the existing structures in the countryside and, together with this, the sustainability of local architecture and construction traditions in new constructions [13].

Local architecture is adaptable or exhibits features that can be improved over time as needs and conditions change. It is the basis for the sustainability of the interpretation of architectural designs in terms of the value of the local architects' own structure and the current technology. While local characteristics are being maintained, building a balance between the past and the future, depending on changing conditions, makes the architecture sustainable [14]. (Ovalı and Delibas, 2016).

The purpose of sustainable construction is "The creation and management of healthy environments based on the effective use of resources and ecological design". While traditional construction in rural settlements focuses on cost, performance and quality objectives, sustainable construction focuses on these goals in addition to minimizing resource consumption and environmental degradation and creating a healthy environment [13]. Sustainable structure can be summarized as a reflection of sustainability and sustainable development in the construction sector. Three sustainability indicators stand out in sustainable structures. These; Ecological sustainability, economic sustainability and social / cultural sustainability.

There exist several studies about rural structures and some of them given in Table 2. Table II summarizes scientific works available in the literature considering sustainability of the rural structures. 
Table 2. Some works available in the literature about sustainability of rural structures

\begin{tabular}{|c|c|c|c|}
\hline Authors & Year & $\begin{array}{l}\text { Fields } \\
\text { application }\end{array}$ & es of the evaluation \\
\hline $\begin{array}{l}\text { Tasci and } \\
\text { Pekdogan } \\
{[1]}\end{array}$ & 2015 & $\begin{array}{l}\text { Sustainability, } \\
\text { ecology, rural } \\
\text { settlements, }\end{array}$ & $\begin{array}{l}\text { To evaluated rural area and } \\
\text { structures in terms of settlement } \\
\text { of topography, relationship } \\
\text { between green texture and } \\
\text { housing, space organization also } \\
\text { building materials and building } \\
\text { forms variances }\end{array}$ \\
\hline $\begin{array}{l}\text { Altinkaya } \\
\text { at all. [15] }\end{array}$ & 2011 & $\begin{array}{l}\text { Sustainable housing, } \\
\text { rural settlement }\end{array}$ & $\begin{array}{l}\text { To evaluated Sustainability in } \\
\text { Rural Settlements }\end{array}$ \\
\hline Kusat [16] & 2014 & $\begin{array}{l}\text { Rural development, } \\
\text { Rural area, } \\
\text { Sustainable } \\
\text { development }\end{array}$ & $\begin{array}{l}\text { To evaluated sustainable rural } \\
\text { development }\end{array}$ \\
\hline $\begin{array}{l}\text { Gorgulu } \\
\text { and Koman } \\
{[13]}\end{array}$ & 2013 & $\begin{array}{l}\text { Rural housing, } \\
\text { sustainable rural } \\
\text { development, rural } \\
\text { setlements, masonry } \\
\text { construction. }\end{array}$ & $\begin{array}{l}\text { To determine a masonry wall } \\
\text { type for rural housing in the case } \\
\text { of Kayseri }\end{array}$ \\
\hline $\begin{array}{l}\text { Sagıroglu } \\
\text { and } \\
\text { Karayazı } \\
{[17]}\end{array}$ & 2017 & $\begin{array}{l}\text { Rural Dwellings, } \\
\text { Sustainability, }\end{array}$ & $\begin{array}{l}\text { To Preservation of Traditional } \\
\text { Rural Dwellings }\end{array}$ \\
\hline $\begin{array}{l}\text { Ovali and } \\
\text { Delibas }[14]\end{array}$ & 2016 & $\begin{array}{l}\text { Environmental } \\
\text { sustainability, } \\
\text { vernacular } \\
\text { architecture }\end{array}$ & $\begin{array}{l}\text { Analysis of rural area Within the } \\
\text { Scope of the Sustainability of the } \\
\text { Vernacular Architecture }\end{array}$ \\
\hline $\begin{array}{l}\text { Arpacioglu } \\
\text { at all. [19] }\end{array}$ & 2016 & $\begin{array}{l}\text { Rural Sustainability, } \\
\text { Adobe, Traditional } \\
\text { Construction, } \\
\text { Energy Efficiency }\end{array}$ & $\begin{array}{l}\text { To Conservation of Village } \\
\text { Houses in the Context of Rural } \\
\text { Sustainability }\end{array}$ \\
\hline
\end{tabular}

\section{Conclusion}

Preserving the local architectural heritage and transferring it to future generations is important in terms of sustainability. Local architecture must be studied and assimilated in order to determine the knowledge of production cultures based on experience and to convey the knowledge acquired in the production cultures created today.

Traditional settlements have been produced from existing sources, from readily available and transformable materials. They use the available resources to maintain thermal comfort without additional measures and thus carry sustainability principles. It is observed that traditional textures have a certain ecological sensitivity when their production and usage stages in the historical process are examined.

from a theoretical basis.

\section{References}

[1]. Tasc1, B., Pekdogan, T. (2015). Examination of Traditional Dwelling Architecture in Rural Settlements in The Context of Sustainability : Kozbeyli. 2 nd International Sustainable Buildings Symposium, 658-664.

[2]. Esin, T., \& Yüksek, İ. (2008). A study on ecological properties of building materials used in traditional buildings (in Turkey). Facilities, 26(5/6), 229-241.

[3]. Zolfani, S. H., \& Zavadskas, E. K. (2013). Sustainable development of rural areas' building structures based on local climate. Procedia Engineering, 57, 1295-1301.

[4]. Bragança, L., Mateus, R., \& Koukkari, H. (2010). Building sustainability assessment. Sustainability, 2(7). 
[5]. Mateus, R., \& Bragança, L. (2011). Sustainability assessment and rating of buildings: Developing the methodology SBTool PT-H. Building and Environment, 46(10), 1962-1971.

[6]. http://www.tradingeconomics.com/turkey/rural-population-percent-of-total-population-wb-data.html

[7]. Bayülke N., 1984. Doğu Anadolu'daki Kırsal Konutların Deprem Davranışları Ve 30 Ekim 1983 Horasan Depreminde Gözlenmiş Hasar, Kuzeydoğu Anadolu I. Ulusal, Deprem Sempozyumu, Erzurum.

[8]. rıoğlu E.,Anadol K., 1974. Türkiye'de Kırsal Konutların Son Yıllardaki Tahripkar Depremlere Mukabelesi , Deprem Araştırma Bülteni, s:5, Ankara.

[9]. Gür, M., Cagdas, V., \& Demir, H. (2003, December). Urban-Rural Interrelationship and Issues in Turkey. In 2nd FIG Conference, Marrakech, Morocco (pp. 2-5).

[10].Doğangün, A., Tuluk, Ö. İ., Livaoğlu, R., \& Acar, R. (2006). Traditional wooden buildings and their damages during earthquakes in Turkey. Engineering Failure Analysis, 13(6), 981-996.

[11].Korkmaz, H. H., Korkmaz, S. Z., \& Donduren, M. S. (2010). Earthquake hazard and damage on traditional rural structures in Turkey. Natural Hazards and Earth System Sciences, 10(3), 605.

[12].Korkmaz S.Z. (2007). Seismic improvement of rural houses, Selcuk University, Graduate school of natural sciences, Architecture Department, Phd Thesis, Konya.

[13].Gorgulu, H.C., Koman, I. (2013). Kayseri Kırsalındaki Yığma Konutlar için Duvar Tipi Önerisi, Tasarim+Kuram, (15) 56-70.

[14].Ovali, P. K., \& Delibaş, N. (2016). Yerel Mimarinin Sürdürülebilirliği Kapsamında Kayaköy’ün Çözümlemesi.

[15].Altinkaya, E.P., Tekin, C., \& Eren. O. (2011)Sustainability in Rural Settlements: Adatepe and Demirciköy in Ayvacık Town in Çanakkale, Journal of Polytechnic, Vol: 14 No: 2 pp. 109-113.

[16].Kusat. N. (2014). Rural Tourism as an Alternative For Sustainable Rural Development and Its Applicability in Turkey, The International Journal of Economic and Social Research, Vol. 10, Year 10, No. 2.

[17].Sağiroğlu, Ö., \& Karayazı, S. S. Akseki Belenalan Köyü Geleneksel Kirsal Konut Dokusunda Korumanin; Ekoturizm Yolu İle Sürdürülebilirliğinin Tespiti.

[18].Arpacioglu, U., Ozgunler, M. \& Ozgunler S.E. (2016). Kırsal Sürdürülebilirlik Bağlamında Köy Evlerinin Korunması İçin Cephe ve Çatı Yaklaşımlarında Yeni Bir Model Köyünü Yaşat Projesi, 8. Ulusal Çatı \& Cephe Sempozyumu 2- 3 Haziran 2016 Mimar Sinan Güzel SanatlarÜniversitesi Fındıkl1İstanbul 